1995

\title{
Some Thoughts on Recent Efforts to Further Systematize Goffman
}

James J. Chriss

Cleveland State University

Follow this and additional works at: https://engagedscholarship.csuohio.edu/clsoc_crim_facpub

Part of the Criminology Commons

How does access to this work benefit you? Let us know!

Publisher's Statement

The final publication is available via http://link.springer.com/article/10.1007\%2FBF02098570

\section{Repository Citation}

Chriss, James J., "Some Thoughts on Recent Efforts to Further Systematize Goffman" (1995). Sociology \& Criminology Faculty Publications. 99.

https://engagedscholarship.csuohio.edu/clsoc_crim_facpub/99

This Article is brought to you for free and open access by the Sociology \& Criminology Department at EngagedScholarship@CSU. It has been accepted for inclusion in Sociology \& Criminology Faculty Publications by an authorized administrator of EngagedScholarship@CSU. For more information, please contact library.es@csuohio.edu. 


\title{
Some Thoughts on Recent Efforts to Further Systematize Goffman
}

\author{
James J. Chriss ${ }^{1}$
}

\section{INTRODUCTION}

Erving Goffman (1922-1982) was certainly one of the most influential sociologists of the post-World War II era. As citation data from Social Science Citation Index and other sources indicate (see, e.g., Bock 1988; Chriss 1995a; MacCannell 1983; Oromaner 1980), interest in Goffman remains high both within sociology proper and in an ever-expanding number of disciplines across the social sciences and humanities as each "discovers" Goffman and begins to assimilate his writings into their respective disciplinary canons. $^{2}$

Since Goffman's death in 1982 there have been a number of symposia, edited volumes, and full-length monographs dedicated to examining all or parts of his work. Two edited volumes appeared in the $1980 \mathrm{~s}$, beginning with Ditton (1980), and then followed by Drew and Wootton's ethnomethodologically oriented exegesis (1988). A year later the journal Human Studies published a symposium dedicated to exploring the phenomenological and philosophical roots of Goffman's thought, especially with respect to his substantive work on verbal forms of self-presentation (see the contributions by Atkinson 1989; Davies 1989; Hinnenkamp 1989; Rawls 1989; Smith 1989; Waksler 1989; Yearley and Brewer 1989).

The 1990s have witnessed a continuing efflorescence in Goffman scholarship, as represented in such articles as Bovone (1993), Chriss (1995b,

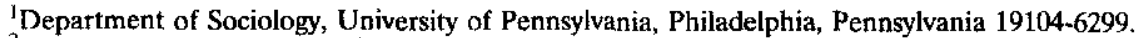
${ }^{2}$ Some examples of this interdisciplinary stocktaking and application of Goffman are Abrahams (1984) and Becker (1984)-linguistics; Bock (1988) and Callan (1970)-anthropology; Braithwaite (1993)-criminology; Cottle (1994)-communications; Erwin (1992)-ethology; Kainan (1994)-education; Langman (1991) and Vester (1989)-postmodernism and semiotics: Heinich (1993) and Miller (1984)-aesthetics and philosophy: and Warburton (1992)--photography
} 
1995c), Gonzales (1993), Hartland (1994), Malone (1994), Schwalbe (1993), Stein (1991), and Travers (1994b). Monographs have also continued to appear, beginning with Stephen Riggins' (1990) edited volume dedicated primarily to semiotic interpretations and extensions of Goffman's major concepts (also see Chriss, 1993b). A few years later two more full-length monographs on Goffman were released, first from Tom Burns (1992), and then later from Philip Manning (1992). ${ }^{3}$ I turn next to a summary and evaluation of Manning's effort.

\section{MANNING AND THE SIAC SCHEMA}

The major contribution of Manning's book is that it argues convincingly for and illustrates explicitly the centrality of Goffman's microsociology for contemporary sociology. Although Goffman was a master at producing terminology and taxonomic schemes for ordering his observations with respect to particular substantive areas-e.g., total institutions, public behavior, strategic interaction, role distance, and so forth-Goffman's work at times comes across as overly episodic because of his occasional habit of introducing concepts only to drop them with the release of each subsequent work (see, e.g., Gouldner 1970).

Manning has contributed a sense of stability to Goffman's concepts and nascent general theory of copresence by distilling from his writings four broad assumptions. These assumptions coalesce into an overarching project which Manning refers to as the SIAC schema, its components consisting of (1) situational propriety, (2) involvement, (3) accessibility, and (4) civil inattention. ${ }^{4}$

"Situational propriety" links Goffman's dramaturgical metaphor to the idea of frames (Goffman, 1974) insofar as the meanings of social action

${ }^{3}$ Additionally, an edited volume is forthcoming entitled Goffman's Patrimony (Smith, 1995). There have aiso recently appeared a handful of foreign-language articles and volumes dedicated to biographical analysis of Goffman and/or exegeses of his various texts. See, for example, Bovone and Rovati (1992)-Italian; Fukazawa (1982), Hirakawa (1983), and Maruki (1986)-Japanese; Hettlage and Lenz (1991)-German; Joseph (1989) and Winkin (1988)French; and Kravchenko (1993)-Russian.

${ }^{4}$ I would suggest that Parsons' four function (AGIL) scheme may be applicable to the interaction order as well, meaning that the SIAC schema or some close relative could be delineated with reference to the functions of adaptation, goal-attainment, integration, and latent pattern maintenance. The rituals of copresence-such as those embodied in openings, closings, involvement contours, territories of the self, tie signs, turn taking in talk, rules of relevance and irrelevance, and so forth-point toward the suggestion that face-to-face interaction (or the interaction order) can be thought of as a little boundary-maintaining system that tends toward a state of equilibrium (see, e.g, Callan, 1970). Further research into the possible functional parallels between AGIL and SIAC may prove useful in further systematizing Goffman's observations. 
(the drama) arise or can be made sense of only with respect to the situation (the scene) within which such action is played out or sustained. The idea of situational propriety suggests, following Simmel, that process (or content) can only be understood with respect to structure (or form) and vice versa (see, e.g., Frankford's, 1994:1120, discussion of substantive vs. procedural norms). A simple misunderstanding or miscommunication can, for example, escalate into a potentially fearful or threatening confrontation in those instances where situational proprieties are either highly circumscribed or the stability of the environment within which the encounter occurs is tenuous or simply not taken for granted. ${ }^{5}$

As an example, one Saturday evening around 6:15 I was in downtown Philadelphia ("Center City") waiting at a bus stop. Inexplicably, however, when the bus approached it did not stop but continued on as if to suggest the driver had not noticed my presence there (I happened to be the only person at the stop). I waved my arms frantically as the bus passed, and even ran alongside it for a block or so in an attempt to catch up or at least attract the driver's attention. Because it was unseasonably warm and because I was not in the best of shape to begin with, I had managed to work up a fairly good sweat. Resigned to the fact that I had missed the bus, I decided to meander around and perhaps find a place to eat.

I spotted a small but somewhat upscale eatery tucked away down a flight of stairs just off the comer of a busy intersection. The restaurant had apparently just opened its doors for the dinner hour, and no one was there save for a cashier, a hostess, and some kitchen help. It was also quite dark.

Imagine this scene: I was groping around because it was dark and because I was not familiar with the layout of the restaurant. I was still sweaty and somewhat out of breath. When I walked in I looked around briefly, then turned to the hostess to ask "Can I see a menu?" She glanced at me with a somewhat puzzled look, then pointed toward the other end of the restaurant without saying a word. I assumed she meant that the menus were on the tables. I walked over to several tables, saw no menus, walked around a little more, then returned to the counter. By this time the hostess was conferring with the female cashier and a fellow from the kitchen, and in that moment there was a palpable sense that these people were worried about something; they were worried in fact about me. I repeated my request, "May I please see a menu?" and made sure to enunciate my words

\footnotetext{
${ }^{5}$ Much of Goffman's (1971:238-333) theory of the predictability of social life hinges on the fact that actors strive to present images of themselves that appear normal or sane to others. Andrew Travers (see, e.g., 1991, 1992, 1994a) is one theorist who has explored in some detail the weaknesses of this line of Goffman's thinking, suggesting that such a reliance by Goffman on the force of normal appearances in creating and sustaining social order paradoxically disempowers the creation of morally responsible selves.
} 
more carefully than I had previously. This time the hostess let out an audible sigh of relief and explained, "I thought you asked to use the men's room. We didn't know what you were up to!"

Several factors converged to produce this little disturbance, much of the action in the scene driven by the situational proprieties residing at two levels or frames of understanding. At the micro level, the situational proprieties of an upscale eatery suggest that patrons ought to present themselves in such a way that their intentions are clear and nonthreatening. The presumption is that anyone entering the establishment is there to get something to eat, and consistent with this is the expectation that such persons should be dressed appropriately for the occasion. On the other hand, a lone male entering the restaurant with a somewhat disheveled appearance and seemingly confused state who asks to use the restroom with no clear indication of actually wanting to eat may, in those few fleeting and liminal moments, appear to the workers in attendance as "strange," "crazy," "scary," or according to Goffman's (1953) apt characterization, as a "faulty person."

At the macro level, I would suggest another range of situational propriety was operating whereby persons, and especially service workers or those working with the general public, possess a general or stereotypical understanding concerning what types of persons to expect or to be on guard against in downtown Philadelphia. I have lived most of my life in the South, and I would suggest that, all things being equal, Philadelphians are, in comparison to Southerners, more on guard, more cynical, and more likely to view suspiciously persons who give just the slightest hint of instability or lack of commitment to the tacit norms of public comportment or demeanor. It is highly unlikely, for example, that this particular restaurant misunderstanding would have escalated as far as it did had it occurred in, say, Austin, Texas, or Roanoke, Virginia. ${ }^{6}$ We see then the importance of situational propriety and cultural contingencies in infusing actors with meaning about what to expect in their face-to-face encounters.

The second element of the SIAC schema is "involvement," which refers to our capacity to give or withhold attention to whatever activity is at hand (Manning, 1992:12; Goffman, 1963:43-79). Much of social life revolves around the subtle rules of access to or exit from participation in any number of social gatherings or encounters. There are a range of cues and rituals available to individuals by which they may signal to others present the ex-

${ }^{6}$ Granted, Austin and Roanoke are smaller cities than Philadelphia, so one might argue that whatever differences I have observed result from the difference in population size, not geographical differences. But it has been my experience that these same contrasts in culture, behavior, and spatial arrangements hold even for Southern cities that are closer in size to Philadelphia, such as Houston, Texas, or Tidewater, Virginia. 
tent to which they are or are not ratified participants in such gatherings (e.g., rounds of talk, waiting in queues, parties, board meetings, political rallies, etc.).

We of course sometimes "shield" our level of involvement when we are not ratified participants in an activity, and a variety of props are available for this work. For example, we may feign reading a paper while eavesdropping on a nearby conversation. Likewise an open display of uninvolvement may be called for in situations where one finds oneself uncomfortably close, in terms of physical proximity, to another individual or to a particular strip of activity. For example, most persons waiting in line to use automatic teller machines make quite a show of standing back an appropriate distance or looking away so as to reinforce to others their own sense of disinterestedness. ${ }^{7}$

The third and fourth elements of SIAC are "accessibility" and "civil inattention." Issues of accessibility run concurrently with involvement, insofar as there are rules and rituals of access that guide appropriate levels of involvement for persons in particular focused or unfocused gatherings. For example, greater levels of access are afforded to those who are familiar to each other, and this familiarity designates that participation by familiar others is ratified in a wide range of settings and contexts. However, even nonfamiliar others are granted specific levels of access to persons in most public settings, as for example when a stranger on the street approaches to ask the time of day. Intruding upon another to ask the time is but one of the minor courtesies persons extend to one another, and these interaction rituals go a long way toward upholding the sense of predictability and civility of public places. Without such promise of accessibility, social life would become unbearably confrontational and contentious. Ultimately, Goffman's attentiveness to the ways in which these daily rituals serve to uphold and reaffirm civil society is the direct embodiment, in modern dress, of Emile Durkheim's notion of the "cult of the individual" (Chriss, 1993a). ${ }^{8}$

"Civil inattention," the fourth component of the SIAC schema, is a public sign of deference by which persons acknowledge the presence of others while not overstepping the bounds of routine levels of circumspection. Goffman (1963) has aptly described the work of civil inattention in the case of strangers passing each other on a city street:

\footnotetext{
${ }^{7}$ It is my impression that Philadelphians in queue to use automatic teller machines place much more distance between themselves and the customer at the machine than is the case in Texas or throughout the South. Although my evidence for this is merely anecdotal, it would probably be fairly easy to gather empirical data for purpostes of determining whether this difference, if it actually exists, is statistically significant.

${ }^{8}$ Notice, however, the recent trend toward the wearing of headphones in public places. A person wearing such a device more or less signals to others that they are simply not accessible at the moment. and perhaps neither for the foresceable future as well.
} 
Where the courtesy is performed between two persons passing on the street, civil inattention may take the special form of eyeing the other up to approximately eight feet, during which time sides of the street are apportioned by gesture, and then casting the eyes down as the other passes-a kind of dimming of lights. (p. 84)

In our modern civil society, eye-work (e.g., Anderson, 1990), or the rules of eye contact more generally, is one of the most consistently invoked and honored rules guiding encounters between nonfamiliar others. Further, these tacit rules of civil attention become even more crucial the more tenuous or problematic the social order is or is perceived to be, such as for example on the streets of the inner city (Anderson, 1994) or even in nudist camps (Weinberg, 1994).

\section{GENERAL THEORY, FRAGMENTATION, AND SYNTHESIS}

Manning's SIAC schema is an important step forward in the ongoing effort to order Goffman's somewhat episodic insights into a coherent whole. Many scholars are now busily at work systematizing Goffman's writings in order to fashion something that Goffman merely hinted at during his lifetime: a general theory of social interaction or face-to-face behavior (see, e.g., Chriss, 1993b; Collins, 1987; Giddens, 1984, 1988; Manning, 1992; and Turner, 1988, 1994).

Goffman's work is central to the debate over the possibility or desirability of general sociological theory, especially in light of the postmodernist impulse toward the rejection of the grand narratives of Enlightenment philosophy, and the positing instead of the loss of epistemological certitude (see, e.g., Agger, 1991; Clough, 1992; Crook, 1991; Gouldner, 1970; Jameson, 1991; Lyotard, 1984; Seidman, 1994).

One of the implications of this theorized loss of certitude (e.g., the "end of the subject" or even "the end of sociology") is the move toward greater and greater sectarianism in or fragmentation of sociology and the social sciences more generally (see, e.g., Horowitz, 1993; Nash and Wardell, 1993; Turner 1989). Years ago, for example, Alvin Gouldner (1970) wrote a scathing critique of the discipline wherein he predicted that the thendominant theoretical perspective, functionalism, was heading toward entropy. He predicted that a new era was emerging within sociology, one that would be marked by what he called a theoretical "polycentrism"-namely, a situation whereby a variety of competing theoretical perspectives would battle for supremacy.

Sociology is presently going through such a period of eclecticism and fragmentation, that is, there is no single perspective hogging the theoretical spotlight (although rational choice theory is making moves in that direc- 
tion). What is crucial to note, however, is that even with this current proliferation of theoretical perspectives, each has at least an implicit theory of social action, that is, some underlying assumptions regarding the nature (or ontology) of human behavior. Because Goffman is such a major figure in the discipline, each perspective has had to confront at some level (some more directly than others of course) the implications of Goffman's dramaturgical theory of action, especially with regard to his ideas concerning the presentation of self and the process of impression management.

Recent efforts in metatheorizing (e.g., Ritzer, 1991) reflect a new direction in sociology-call it the "synthetic turn"-which is attempting to find connections between the seemingly disparate theoretical perspectives marking the current age of polycentrism (for a recent comment on the issues of theoretical synthesis and fragmentation, see Holmwood and Stewart, 1994). I contend that by analyzing Goffman's works in the manner described above, and with the help of secondary systematizing schemes such as Manning's, an important contribution can be made to the larger metatheoretical project. ${ }^{9}$ Eventually, this multidimensional stocktaking of Goffman's work will bring us into closer agreement about the essentials of human conduct, and it is this crucial starting point that we as sociologists have simply overlooked or taken for granted for far too long.

\section{ACKNOWLEDGMENTS}

I would like to thank Gary Marx, Teresa Labov, Eli Anderson, Andrew Travers, and Greg, Smith for their helpful comments on earlier drafts of this essay.

\section{REFERENCES}

Abrahams, Roger D.

1984 "Goffman reconsidered: Pros and Agger, Ben players." Raritan 3(4):76-94.

1991 "Critical theory, poststructuralism, postmodernism: Their sociological relevance." Annual Review of Sociology 17:105-131.

\section{Anderson, Elijah}

1990 Streetwise: Race, Class and Change in an Urban Community. Chicago: University of Chicago Press.

\footnotetext{
${ }^{9}$ What is needed is a concerted interparadigmatic dialogue that analyzes and assesses the works of a number of important or central figures in the discipline. In bringing together this multiperspectival analysis of Goffman, for example, the hope is to further illustrate the importance and utility of metatheory in helping to shatter some of the myths associated with seemingly incompatible theoretical perspectives. What ultimately would be highlighted then are the continuity and convergences between these various interpretations of Goffman.
} 
Anderson, Elijah

1994 "The code of the streets." Atlantic Monthly (May): 81-94.

Atkinson, Paul

1989 "Goffman's poetics." Human Studies 12(1):59-76.

Becker, Alton L.

1984 "Goffman's animated language game." Raritan 3(4):95-112.

Bock, P. K.

1988 "The importance of Erving Goffman to psychological anthropology." Ethos 16(1):3-20.

\section{Bovone, Laura}

1993 "Ethics as etiquette: The emblematic contribution of Erving Goffman." Theory, Culture \& Society 10:25-39.

Bovone, Laura and G. Rovati, eds.

1992 L'ordine dell'interazione: la sociologia di Erving Goffman. Milano: Vita e Pensiero.

Braithwaite, J.

1993 "Shame and modernity." British Journal of Criminology 33(1):1-18.

Burns, Tom

1992 Erving Goffman. New York: Routledge.

Callan, Hilary

1970 Ethology and Society: Toward an Anthropological View. Oxford: Clarendon Press.

Chriss, James J.

1993a "Durkheim's cult of the individual as civil religion: Its appropriation by Erving Goffman." Sociological Spectrum 13(2):251-275.

1993b "Looking back on Goffman: The excavation continues." Human Studies 16(4):469-483.

1995a "Testing Gouldner's coming crisis thesis: On the waxing and waning of intellectual influence." Current Perspectives in Social Theory 16: (forthcoming).

$1995 \mathrm{~b}$ "Role distance and the negational self." In G. W. H. Smith (ed.), Goffman's Patrimony. London: Routledge (forthcoming).

1995c "Habermas, Goffman, and communicative action: Implications for professional practice." American Sociological Review (forthcoming).

Clough, Patricia T.

1992 The End(s) of Ethnography: From Realism to Social Criticism. Newbury Park: Sage.

\section{Collins, Randall}

1987 "Interaction ritual chains, power and property: The micro-macro connection as an empirically based theoretical problem." In J. C. Alexander, B. Giesen, R. Munch, and N. J. Smelser (eds.), The Micro-Macro Link: 193206. Berkeley: University of California Press.

Cottle, S.

1994 "Stigmatizing Handsworth: Notes on reporting spoiled space." Critical Studies in Mass Communication 11(3):231-256.

Crook, Stephen

1991 Modern Radicalism and its Aftermath: Foundationalism and AntiFoundationalism in Radical Social Theory. London: Routledge.

Davies, C.

1989 "Goffman's concept of the total institution: Criticisms and revisions." $\mathrm{Hu}-$ man Studies 12(1):77-96.

Ditton, Jason, ed.

1980 The View from Goffman. New York: St. Martin's Press.

Drew, Paul and Anthony Wootton, eds.

1988 Erving Goffman: Exploring the Interaction Order. Cambridge: Polity Press.

Erwin, Robert

1992 "The nature of Goffman." Centennial Review 36(2):327-342.

Frankford, David $M$.

1994 "The critical potential of the common law tradition." Review essay of David Sciulli's The Theory of Societal Constitutionalism. Columbia Law Review 94(3):1076-1123.

Fukazawa, Kenji

1982 "On Erving Goffman's concept of role distance" [title appears in Japanese]. Soshioroji 26(3):27-42.

\section{Giddens, Anthony}

1984 The Constitution of Society: Outline of the Theory of Structuration. Cambridge, UK: Polity.

\section{Giddens, Anthony}

1988 "Goffman as a systematic social theorist." In P. Drew and A. Wootton (eds.), Erving Goffman: Exploring the Interaction Order: 250-279. Cambridge: Polity Press.

Gofiman, Erving

1953 "Communication conduct in an island community." Ph.D. dissertation, University of Chicago. 
1963 Behavior in Public Places. New York: Free Press.

1971 Relations in Public. New York: Harper \& Row.

1974 Frame Analysis. Boston: Northeastern University Press.

Gonzales, P. B.

1993 "Shame, peer, and oscillating frames in DWI conviction: Extending Goffman's sociological landscape." Symbolic Interaction 16(3):257-271.

\section{Gouldner, Alvin W.}

1970 The Coming Crisis of Western Sociology. New York: Basic.

Hartland, N, G.

1994 "Goffman's attitude and social analysis." Human Studies 17:251-266.

\section{Heinich, Nathalie}

1993 "Framing the bullfight: Aesthetics versus ethics." British Journal of Aesthetics 33(1):52-58.

Hettlage, Robert and Karl Lenz, eds.

1991 Erving Goffman: ein soziologischer Klassiker der zweiten Generation. Bern: Haupt.

Hinnenkamp, V.

1989 "'Turkish man you?' The conversational accomplishment of the social and ethnic category of 'Turkish guest. worker.'" Human Studies 12(1):117146.

\section{Hirakawa, Shigeru}

1983 "'Appearances': Some notes on E. Goffman's 'situational approach.' " [title appears in Japanese] Soshioroji 28(2):1-16.

Holmwood, John and Alexander Stewart

1994 "Synthesis and fragmentation in social theory: A progressive solution." Sociological Theory 12(1):83-100.

\section{Horowitz, Irving Louis}

1993 The Decomposition of Sociology. New York: Oxford University Press.

\section{Jameson, Fredric}

1991 Postmodernism, or the Cultural Logic of Late Capitalism. Durham, NC: Duke University Press.

Joseph, Isaac, ed.

1989 Le parler frais d'Erving Goffman. Paris: Editions de Minuit.

\section{Kainan, $\boldsymbol{A}$.}

1994 "Staffroom grumblings as expressed teachers" vocation." Teaching and Teacher Education 10(3):281-290.
Kravchenko, E.

1993 "Creating and knowing one's self: The social dramaturgy of Erving Goffman." Sotsiologicheskie Issledovaniya 11:58-66.

\section{Langman, Lauren}

1991 "Alienation and everyday life: Goffman meets Marx at the shopping mall." International Journal of Sociol* ogy and Social Policy 11(6-8):107-124.

Lyotard, Jean-Francois

1984 The Postmodern Condition. Minneapolis: University of Minnesota Press.

MacCannell, Dean

1983 "Erving Goffman (1922-1982)." Semiotica 45(1/2):1-33.

Malone, $\mathbf{M}$. $\mathbf{J}$.

1994 "Small disagreements: Character contests and working consensus in informal talk." Symbolic Interaction 1.7(2):107-127.

Manning, Philip

1992 Erving Goffman and Modern Sociology. Stanford: Stanford University Press.

\section{Maruki, Keisuke}

1986 "Everyday experience and interaction theory: On E. Goffman's dramaturgy." ititle appears in Japanese] Shakaigaku-Hyoron [Japanese Sociologica] Review] 37(1):24-34.

Miller, Thomas G.

1984 "Goffman, social acting, and moral behaviour." Journal for the Theory of Social Behaviour 14(2):141-163.

Nash, Bradley, Jr, and Mark Wardell

1993 "The control of sociological theory: In praise of the interregnum." Sociological Inquiry 63(3):276-292.

Oromaner, Mark

1980) "Erving Goffman and the academic community." Philosophy of the Social Sciences 10:287-291.

Rawls, Anne W.

1989 "Language, self, and social order: A reformulation of Goffman and Sacks." Human Studies 12(1):147-172.

Riggins, Stephen, ed.

1990 Beyond Goffman: Studies on Commurication, Institution, and Social Interaction. Berlin: Mouton de Gruyter.

Ritzer, George

1991 Metatheorizing in Sociology. Lexington, MA: Lexington. 
Schwalbe, $M$.

1993 "Goffman against postmodernism: Emotion and the reality of the self." Symbolic Interaction 16(4):333-350.

Seidman, Steven

1994 Contested Knowledge. Oxford: Blackwell.

Smith, Gregory W. H.

1989 "Snapshots 'sub specie aeternitatis': Simmel, Goffman and formal sociology." Human Studies 12(1):19-58.

Smith, Gregory W. H., ed.

1995 Goffman's Patrimony. London: Routledge (forthcoming).

Stein, Michael

1991 "Sociology and the prosaic." Sociological Inquiry 61(4):421-433.

Travers, Andrew

1991 "From 'normal appearances' to 'simulation' in interaction." Journal for the Theory of Social Behaviour 21(3):297337.

1992 "The conversion of self in everyday life." Human Studies 15 (2-3):169-238.

1994a "Destigmatizing the stigma of self in Garfinkel's and Goffman's accounts of normal appearances." Philosophy of the Social Sciences 24(1):5-40.

$1994 \mathrm{~b}$ "The unrequited self." History of the Human Sciences 7(2):121-140.

Turner, Jonathan $H$.

1988 A Theory of Social Interaction. Stanford, CA: Stanford University Press.

1989 "The disintegration of American sociology." Sociological Perspectives 32(4):419-433.
1994 "Roles and interaction processes: Toward a more robust theory." In G. M. Platt and C. Gordon (eds.), Self, Collective Behavior and Saciety: Essays Honoring the Contributions of Ralph H. Turner: 359-376. Greenwich, CT: JAI Press.

Vester, Heinz-Gunter

1989 "Erving Goffman's sociology as a semiotics of postmodern culture." Semiotica 76(3/4):191-203.

Waksler, Frances C.

1989 "Erving Goffman's sociology: An introductory essay." Human Studies 12(1):1-18.

Warburton, Nigel

1992 "Diane Arbus and Erving Goffman: The presentation of self." History of Photography 16:401-404.

Weinberg, Martin S.

1994 "The nudist management of respectability." In P. B. Brezina, C. Selengut, and R. A. Weyer (eds.), Seeing Society: Perspectives on Social Life: 128139. Boston: Allyn and Bacon.

Winkin, Yves, ed.

1988 Erving Goffman: Les moments et Ieurs hommes. Paris: Seuil/Minuit.

Yearley, S. and J. D. Brewer

1989 "Stigma and conversational competence: A conversation analytic study of the mentally handicapped." Human Studies 12(1):97-116. 